\title{
Substitution and ring-opening reactions of an azasubstituted [5]ferrocenophane: preparation of 1,1'-unsymmetrically disubstituted ferrocenes
}

\author{
Juan L. López, Alberto Tárraga,* and Pedro Molina* \\ Departamento de Química Orgánica. Facultad de Química, Campus de Espinardo, Universidad \\ de Murcia, E-30100 Murcia, Spain \\ E-mail:pmolina@um.es
}

Dedicated to Professor Joan Bosch on the occasion of her $60^{\text {th }}$ birthday

\begin{abstract}
New synthetic routes to $1,1^{\prime}$-unsymmetrically disubstituted ferrocene ligands bearing a quinoline ring directly linked to the ferrocene unit, along with the synthesis of a new structural motif based on an azasubstituted [5]ferrocenophane which incorporates a dihydroquinoline subunit, are presented.
\end{abstract}

Keywords: Ferrocenophanes, 1,1'- disubstituted ferrocenes; ferrocenyl-quinolines; ferrocenyl carbenium ions

\section{Introduction}

New methods to obtain selectively ferrocenyl structures are of great interest because of the booming involvement of ferrocene derivatives in various fields such as catalysis, organic synthesis, new materials such as liquid crystals or polymers and supramolecular chemistry. ${ }^{1}$ Then, in the last few decades the chemistry of ferrocenes has led to a wide variety of interesting compounds with valuable properties. In this context, much attention has been paid to the study of those ferrocenyl redox-active ligands in which a change in their electrochemical behaviour can be used to monitor complexation of guest species. For this reason, ferrocene derivatives containing atoms with good donor abilities have attracted additional interest, and then, the integration of one or more ferrocene units into a heterocyclic ring system has been recognized to constitute an increasingly important area of molecular recognition.

On the other hand, ferrocenophanes, in which the two cyclopentadienyl rings of ferrocene are joined by an atomic or molecular bridge, retain many of the characteristics of the parent ferrocene and are expected to show unique chemical properties owing to functionality of the side 
arm. There have been many different classes of ferrocenophanes described, most of them possess exclusively carbon-based bridges with three modes of ring attachment ${ }^{2}$ : mononuclear $[\mathrm{m}]$ ferrocenophanes (type I), mononuclear multiply-bridged $[\mathrm{m}]^{\mathrm{n}}$ ferrocenophanes (type II) and multinuclear $\left[\mathrm{m}^{\mathrm{n}}\right]$ ferrocenophanes (type III).

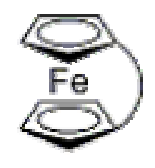

I

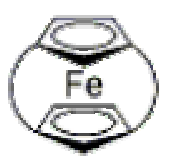

$\|$

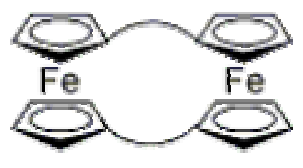

III

\section{Block}

In the frame of our research program on the preparation of both azaheteroaryl substituted ferrocene derivatives ${ }^{3}$ and nitrogen-rich $[\mathrm{m}]^{\mathrm{n}}$ ferrocenophanes ${ }^{4}$ displaying not only redoxswitchable character but also recognition properties for anions and metal cations, we now wish to report new aspects on the reactivity of the recently reported [5]ferrocenophane $\mathbf{1}^{5}$ bearing a 2,4bridged dihydroquinoline ring and efficient routes for its conversion into novel ferrocenylsubstituted quinolines.

\section{Results and Discussion}

The required ferrocene precursor for the synthesis of the new ferrocenyl substituted quinoline derivatives 2, 5, 6 and 7 is the ferrocenophane $\mathbf{1}$, which can be viewed either as a [5]ferrocenophane bearing a 2,4-bridged dihydroquinoline ring or [4](2,4)dihydroquinolinophane containing a 1,1'-disubstituted ferrocene bridge. Compound $\mathbf{1}$ has been prepared by Staudinger reaction of 3-(o-azidophenyl)[5]ferrocenophane-1,5-dione with tri-n-butylphosphine followed by an intramolecular aza-Wittig reaction. ${ }^{5}$ Treatment a methanolic solution of 1,1'-[(3,4-dihydro2,4-quinolinediyl)(2-oxo-1,2-ethanediyl)]-ferrocene 1 ( 1 equiv), containing an excess of $\mathrm{KOH}$, under reflux temperature, afforded the quinoline-ferrocene derivative 2, in 90\% yield (Scheme 1), which was fully characterized using ${ }^{1} \mathrm{H}$ and ${ }^{13} \mathrm{C}$ NMR and mass spectrometry. ${ }^{1} \mathrm{H}$ NMR spectrum shows, as the most characteristic features, the presence of four signals corresponding to the $\mathrm{Cp}$ protons of the ferrocene moiety at $\delta 4.38,4.49,4.62$ and $5.10 \mathrm{ppm}$, in addition to the signals corresponding to the heteroaromatic ring. On the other hand, ${ }^{13} \mathrm{C} \mathrm{NMR}$ is also in agreement with the proposed 1,1'-unsymmetrically substituted structure, showing two sets of three signals each, corresponding to the $\mathrm{CH}$ and quaternary carbon atoms present within the two differently substituted $\mathrm{Cp}$ rings of the ferrocene unit. Formation of $\mathbf{2}$ probably involves an initial proton abstraction on the methylene group at position 4 of the bridge, followed by the cleavage of the cyclophane ring with simultaneous formation of the corresponding enolate, which tautomerizes to the acetyl substituent present at the 1 position of the ferrocene unit. It is worth 
mentioning that $1,1^{\prime}$-unsymmetrically disubstituted ferrocenyl ligands are not very common due to the difficulty in preventing either 1,2-substitution or symmetrical substitution in both cyclopentadienyl $(\mathrm{Cp})$ rings. This unprecedent synthetic methodology constitutes an elegant approach which allows the easy access to a 1,1'-unsymmetrical disubstituted ferrocene in which a quinoline ring is directly linked to one of the $\mathrm{Cp}$ rings of the ferrocene moiety.

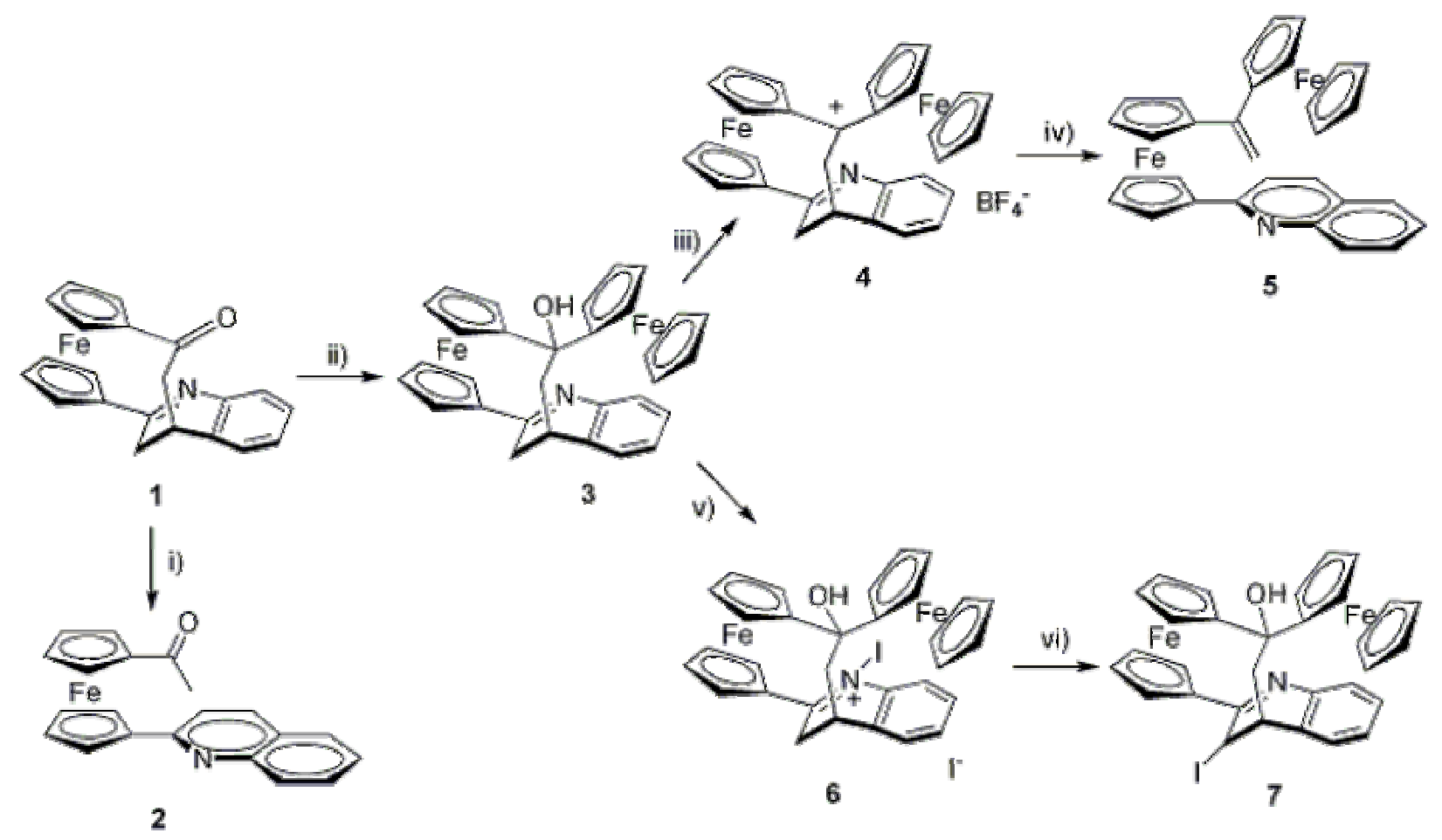

Scheme 1. i) $\mathrm{KOH} / \mathrm{MeOH}, \Delta, 18 \mathrm{~h}$; ;i) FcLi/THF, $\mathrm{N}_{2}, \mathrm{rt}, 10 \mathrm{~min}$; iii) $\mathrm{HBF}_{4}(0.1 \mathrm{M}$ in $\left.\mathrm{CH}_{2} \mathrm{Cl}_{2}\right) / \mathrm{CH}_{2} \mathrm{Cl}_{2}$, r.t., 30 min.; iv) $\mathrm{K}_{2} \mathrm{CO}_{3}(0.1 \mathrm{M}$ in anhydrous $\mathrm{MeOH}), \mathrm{CH}_{2} \mathrm{Cl}_{2}$, r.t., 30 min.; v) $\mathrm{I}_{2} /$ dry toluene, $\mathrm{N}_{2}$, r.t., 1 h.; vi) anhydrous $\mathrm{CHCl}_{3}$, r.t., $72 \mathrm{~h}$.

Likewise, 1,1'-[(3,4-dihydro-2,4-quinolinediyl)(2-ferrocenyl-2-hydroxy-1,2-ethanediyl)]ferrocene 3, obtained from 1 by reaction with ferrocenyllithium ${ }^{6}$, was converted in $30 \%$ yield into 1-( $\alpha$-ferrocenyl)vinyl-1'-(2-quinolyl)ferrocene 5 by a two step synthetic sequence. The first step, outlined in Scheme 1, involves the formation of a tertiary diferrocenylcarbenium ion 4, by treatment of $\mathbf{3}$ with two equivalents of $\mathrm{HBF}_{4}$ in dichloromethane at room temperature. It is worth mentioning that the stepwise addition of $\mathrm{HBF}_{4}$ to a solution of $\mathbf{3}$ resulted in a clear evolution of the color from orange to deep purple, when the carbenium ion was fully formed. The second step involves the reaction of $\mathbf{4}$ with a methanolic solution of potassium carbonate, which should promote a proton abstraction on the methylene group at position 4 of the bridge with concomitant aromatization of the dihydroquinoline ring. It is important to emphasize that in spite of the high reactivity shown by the related (diferrocenyl)methyl carbocations towards methanol ${ }^{7}$ the reaction of $\mathbf{4}$ with methanol in the presence of potassium carbonate provided the 
diferrocenlmethylene derivative 5 instead of the expected methoxy derivative. The structure of the ferrocenylquinoline derivative $\mathbf{5}$ has been fully elucidated from its spectroscopic data. In the ${ }^{1}$ H NMR spectrum of compound 5, the ferrocenyl groups show clearly two sets of well-separated signals in addition to those corresponding to both the vinyl and heterocyclic moieties. This nonequivalence of the two ferrocenyl groups is also showed in its ${ }^{13} \mathrm{C}$ NMR spectrum. The ability of this methodology to provide the homobimetallic complex $\mathbf{5}$, in which the two ferrocene units are coupled intimately, is of major importance due to the interest of this kind of molecular systems, containing more than one metallocene unit, which constitute key targets for the study of intramolecular communication between the covalently linked ferrocene units. ${ }^{8}$

In this context, attempts to promote the formation of a mixed-valence cation derived from compound 3, bearing two metallocene centers, were carried out by partial chemical oxidation. Nevertheles, on treatment with iodine, compound $\mathbf{3}$ did not yield the corresponding mixedvalence derivative but, instead, it was directly converted into the 1-hydroxy-4-iodoferrocenophane 7. Presumably, the reaction involves the initial formation of the intermediate Niododihydroquinolinium salt $\mathbf{6}$, isolated from the reaction medium which, on standing at room temperature, was transformed into 7 through a mechanism which should involve a previous intramolecular dehydrohalogenation followed by a [1,3]-halogen migration process, which is a very well established phenomenon in the azole derivatives ${ }^{9}$ (Scheme 2).
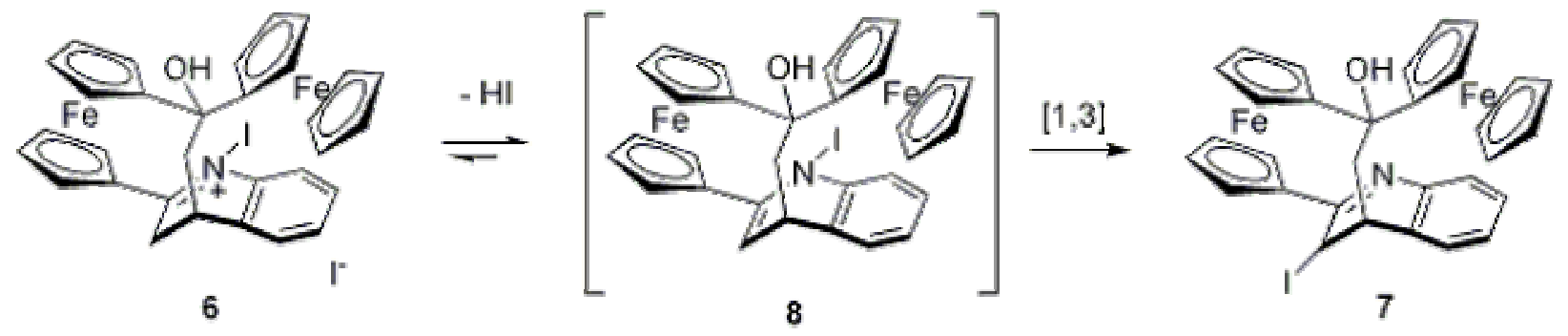

Scheme 2

Compounds 6 and 7 were both fully characterised using ${ }^{1} \mathrm{H}$ and ${ }^{13} \mathrm{C}-\mathrm{NMR}$ and FAB mass spectrometry. In addition, it is worth mentioning that a complete analogy exists between the NMR data of compound 6 and those corresponding to the monoprotonated species obtained upon addition of 1 equivalent of $\mathrm{HBF}_{4}$ to 3 . This observation constitutes additional evidence which demonstrates that in this reaction a quaternization of the dihydroquinoline $\mathrm{N}$ atom takes place and consequently compound $\mathbf{6}$ is then formed. In general, the relative positions and multiplicity of the signals in ${ }^{1} \mathrm{H}-\mathrm{NMR}$ of compound 7 constitutes a useful dataset to demonstrate the substitution at the 4 position of the cyclophane ring by the iodine atom. In fact, together with the characteristic pattern for the signals corresponding to the methylene and methine groups at 2 and 3 positions of the cyclophane bridge, appearing as double doublets at $\delta=1.88$ and $2.38 \mathrm{ppm}$ and as a multiplet at $\delta=3.56-3.58 \mathrm{ppm}$, respectively, a new deshielded methine proton appears, as a doublet, at $\delta=6.24 \mathrm{ppm}$. 
It is worth noting that this transformation proceeded very cleanly, without any traces of side products and, to the best of our knowledge, it constitutes the first example of the preparation of an 1,1,4-unsymmetrically trisubstituted [5]ferrocenophane.

\section{Experimental Section}

General Procedures. All reactions were carried out under $\mathrm{N}_{2}$ and using solvents which were dried by routine procedures. Column chromatography was performed with the use of a column of dimensions $60 \times 4.5 \mathrm{~cm}$ and of silica gel (60 A C.C. $70-200 \mu \mathrm{m}$, sds) as the stationary phase. All melting points were determined on a Kofler hot-plate melting point apparatus and are uncorrected. IR spectra were determined as Nujol emulsions on a Nicolet Impact 400 spectrophotometer. ${ }^{1} \mathrm{H}$ and ${ }^{13} \mathrm{C}$ NMR spectra were recorded at 300 and $400 \mathrm{MHz}$ on a Bruker AC300 and 400. Chemical shifts refer to signals of tetramethylsilane in the case of ${ }^{1} \mathrm{H}$ and ${ }^{13} \mathrm{C}$ spectra. The EI and $\mathrm{FAB}^{+}$mass spectra were recorded on a Fisons AUTOSPEC $500 \mathrm{VG}$ spectrometer, using 3-nitrobenzylalcohol as a matrix. Microanalyses were performed on a Carlo Erba 1108 instrument.

Preparation of 1-(acetyl)-1'-(2-quinolyl)ferrocene (2). To a solution of 1,1'-[3,4-dihydro-2,4quinolinediyl)(2-oxo-1,2-ethanediyl)]ferrocene ${ }^{5} \mathbf{1}(0.1 \mathrm{~g}, 0.22 \mathrm{mmol})$ in freshly distilled $\mathrm{MeOH}$ $(15 \mathrm{ml}) \mathrm{KOH}(0.145 \mathrm{~g}, 2.2 \mathrm{mmol})$ was added and the reaction mixture was heated under reflux temperature for $18 \mathrm{~h}$. After cooling to room temperature, water $(15 \mathrm{ml})$ was added and the product was extracted with $\mathrm{CH}_{2} \mathrm{Cl}_{2}(3 \times 50 \mathrm{ml})$. The organic layer was dried over anhydrous $\mathrm{MgSO}_{4}$ and then the solvent was removed under reduced pressure. The resulting residue was purified by column chromatography on silica gel using ethyl acetate/n-hexane (9/1) as eluent affording the pure compound 2 in $90 \%$ yield. IR (Nujol; $\mathrm{cm}^{-1}$ ): 1684, 1606, 1512, 1283, 1124, 914, 832, 762, 628. ${ }^{1} \mathrm{H}-\mathrm{NMR}\left(\mathrm{CDCl}_{3}\right): \delta 2.23(\mathrm{~s}, 3 \mathrm{H}), 4.38\left(\mathrm{t}, 2 \mathrm{H},{ }^{3} \mathrm{~J}=1.8 \mathrm{~Hz}, \mathrm{Cp}\right), 4.49(\mathrm{t}, 2 \mathrm{H}$, $\left.{ }^{3} \mathrm{~J}=1.8 \mathrm{~Hz}, \mathrm{Cp}\right), 4.62\left(\mathrm{t}, 2 \mathrm{H},{ }^{3} \mathrm{~J}=1.8 \mathrm{~Hz}, \mathrm{Cp}\right), 5.1\left(\mathrm{t}, 2 \mathrm{H},{ }^{3} \mathrm{~J}=1.8 \mathrm{~Hz}, \mathrm{Cp}\right), 7.47(\mathrm{t}, 1 \mathrm{H}, \mathrm{J}=7.8$ $\mathrm{Hz}), 7.5(\mathrm{t}, 1 \mathrm{H}, \mathrm{J}=8.5 \mathrm{~Hz}) 7.67(\mathrm{td}, 1 \mathrm{H}, \mathrm{J}=8.4 \mathrm{~Hz}, \mathrm{~J}=1.3 \mathrm{~Hz}), 7.76(\mathrm{~d}, 1 \mathrm{H}, \mathrm{J}=7.8 \mathrm{~Hz}), 8,03$ $(\mathrm{d}, 1 \mathrm{H}, \mathrm{J}=8.5 \mathrm{~Hz}), 8.07\left(\mathrm{~d}, 1 \mathrm{H}, \mathrm{J}=(8.5 \mathrm{~Hz}) \cdot{ }^{13} \mathrm{C}-\mathrm{NMR}\left(\mathrm{CDCl}_{3}\right): \delta 27.50\left(\mathrm{CH}_{3}\right), 69.35(2 \mathrm{xCH}\right.$, $\mathrm{Cp}), 71.02$ (2xCH, Cp), $71.91(2 \mathrm{xCH}, \mathrm{Cp}), 73.63(2 \times \mathrm{CH}, \mathrm{Cp}), 80.38$ (q, Cp), 85.74 (q, Cp), $119.16(\mathrm{CH}), 125.84(\mathrm{CH}), 126.91(\mathrm{q}), 127.67(\mathrm{q}), 129.05(\mathrm{CH}), 129.66(\mathrm{CH}), 135.97(\mathrm{CH})$, 148.27 (q), 157.46 (q), $201.96(\mathrm{C}=\mathrm{O})$. FAB MS (m/z (relative intensity):356 $\left(\mathrm{M}^{+}+1,100\right)$. Anal. Calcd for $\mathrm{C}_{21} \mathrm{H}_{17} \mathrm{FeNO}$ : C, 71.01; H, 4.82; N, 3.94. Found: C, 69.79; H, 4.61; N, 4.22.

Preparation of 1-( $\alpha$-ferrocenyl)vinyl-1'-(2-quinolyl)ferrocene (5). To a solution of diferrocenyl carbenium tetrafluoroborate $4(0.1 \mathrm{~g}, 0.16 \mathrm{mmol})$ in $\mathrm{CH}_{2} \mathrm{Cl}_{2}(5 \mathrm{ml})$ a solution of 0.1 $\mathrm{M} \mathrm{K}_{2} \mathrm{CO}_{3}$ in dry $\mathrm{MeOH}(8 \mathrm{ml})$ was added and the solution was stirred for $30 \mathrm{~min}$ at room temperature. During this time, a change of the color in the solution, from green to brown, was observed. The solvent was removed under vacuum and the residue was chromatographed on a silica gel column using a mixture of ethyl acetate/n-hexane (3/7) as eluent. Crystallisation from $\mathrm{Et}_{2} \mathrm{O} / n$-hexane $(1: 1)$ gave the pure product in $30 \%$ yield. Mp $117-120^{\circ} \mathrm{C}$. IR (Nujol; $\mathrm{cm}^{-1}$ ) 1604 , 
1526, 1294, 1111, 1050, 853, 774, 741. ${ }^{1} \mathrm{H}-\mathrm{NMR}\left(\mathrm{CDCl}_{3}\right): \delta 4.1(\mathrm{~s}, 5 \mathrm{H}), 4.13\left(\mathrm{t}, 2 \mathrm{H},{ }^{3} \mathrm{~J}=1.8 \mathrm{~Hz}\right.$, $\mathrm{Cp}), 4.20\left(\mathrm{t}, 2 \mathrm{H},{ }^{3} \mathrm{~J}=1.8 \mathrm{~Hz}, \mathrm{Cp}\right), 4.44-4.46(\mathrm{~m}, 4 \mathrm{H}, \mathrm{Cp}), 4.54\left(\mathrm{t}, 2 \mathrm{H},{ }^{3} \mathrm{~J}=2.1 \mathrm{~Hz}, \mathrm{Cp}\right), 5.02(\mathrm{t}$, $\left.2 \mathrm{H},{ }^{3} \mathrm{~J}=2.1 \mathrm{~Hz}, \mathrm{Cp}\right), 5.31\left(\mathrm{~d}, 1 \mathrm{H},{ }^{2} \mathrm{~J}=1.2 \mathrm{~Hz}\right), 5.36\left(\mathrm{~d}, 1 \mathrm{H},{ }^{2} \mathrm{~J}=1.2 \mathrm{~Hz}\right), 7.42-7.48(\mathrm{~m}, 2 \mathrm{H})$, $7.60(\mathrm{td}, 1 \mathrm{H}, \mathrm{J}=7.2 \mathrm{~Hz}, \mathrm{~J}=1.6 \mathrm{~Hz}), 7.67$ (d, 1H, J = 7. $8 \mathrm{~Hz}), 8.00$ (d, 1H, J = 8.4 Hz), 8.03 (d, $1 \mathrm{H}, \mathrm{J}=7.8 \mathrm{~Hz}) .{ }^{13} \mathrm{C}-\mathrm{NMR}\left(\mathrm{CDCl}_{3}\right): \delta 69.68(2 \mathrm{xCH}, \mathrm{Cp}), 69.99(5 \mathrm{xCH}, \mathrm{Cp}), 70.44(2 \mathrm{xCH}, \mathrm{Cp})$, 71.56 (2xCH, Cp), 71.99 (2xCH, Cp), 72.43 (2xCH, Cp), 72.85 (2xCH, Cp), 84.97 (q, Cp), 87.20 (q, Cp), 88.13 (q, Cp), $110.42\left(=\mathrm{CH}_{2}\right), 119.77(\mathrm{CH}), 122.54(\mathrm{q}), 124.63(\mathrm{CH}), 125.23(\mathrm{CH})$, 126.23 (q), $128.09(\mathrm{CH}), 129.62(\mathrm{CH}), 130.06(\mathrm{CH}), 148.20$ (q), 154.00 (q). FAB MS (m/z (relative intensity):524 $\left(\mathrm{M}^{+}+1\right.$, 77). Anal. Calcd for $\mathrm{C}_{31} \mathrm{H}_{25} \mathrm{Fe}_{2} \mathrm{~N}$ : C, 71.16; H, 4.82; N, 2.68. Found: C, 69.89; H, 4.82; N, 2.55.

Preparation of the $\mathbf{N}$-iodo dihydroquinolinium iodide (6). To a solution of $1,1^{\text {' }}$-[3,4-dihydro2,4-quinolinediyl)(2-ferrocenyl-2-hydroxy-1,2-ethanediyl)]ferrocene $\mathbf{3}^{6}(0.1 \mathrm{~g}, 0.37 \mathrm{mmol})$ in freshly distilled toluene, a solution of $\mathrm{I}_{2}(0.140 \mathrm{mg}, 0.55 \mathrm{mmol})$ in the same solvent $(10 \mathrm{ml})$ was added. The reaction mixture was stirred at room temperature and under $\mathrm{N}_{2}$ atmosphere for $1 \mathrm{~h}$. Then, $\mathrm{Et}_{2} \mathrm{O}(25 \mathrm{ml})$ was added and the resulting deep purple precipitated was filtered, washed with dry toluene ( $3 \times 5 \mathrm{ml})$ and crystallized from $\mathrm{CH}_{2} \mathrm{Cl}_{2} /$ toluene (1/1), to give 6 in $60 \%$ yield. Mp 220-222 ${ }^{\circ} \mathrm{C}(\mathrm{d})$. IR (Nujol; $\mathrm{cm}^{-1}$ ) 3565, 1631, 1606, 1572, 1238, 1204, 1160, 1096, 836, 762. ${ }^{1} \mathrm{H}-$ NMR $\left(\mathrm{CDCl}_{3}\right): \delta 1.92\left(\mathrm{t}, 1 \mathrm{H},{ }^{3} \mathrm{~J}=14.4 \mathrm{~Hz}\right), 2.48\left(\mathrm{dd}, 1 \mathrm{H}, \mathrm{J}_{\mathrm{gem}}=14.4 \mathrm{~Hz},{ }^{3} \mathrm{~J}=4.8 \mathrm{~Hz}\right), 2.60(\mathrm{~s}$, $1 \mathrm{H}, \mathrm{OH}), 2.61\left(\mathrm{dd}, 1 \mathrm{H}, \mathrm{J}_{\mathrm{gem}}=15.4 \mathrm{~Hz},{ }^{3} \mathrm{~J}=5.6 \mathrm{~Hz}\right), 3.45(\mathrm{~m}, 1 \mathrm{H}), 3.74\left(\mathrm{~d}, 1 \mathrm{H}, \mathrm{J}_{\mathrm{gem}}=15.4 \mathrm{~Hz}\right)$, 3.89 (m, 1 H, Cp), 4.04-4.07 (m, 3 H, Cp), 4.15-4.16 (m, 1 H, Cp), 4.17-4.18 (m, 1 H, Cp), 4.184.19 (m, 1 H, Cp), 4.20 (s, 5H, Cp), 4.45-4.47 (m, 1H, Cp), 4.80.4.84 (m, 1H, Cp), 4.95-4.97 (m, 2H, Cp), 5.35-5.37 (m, 1H, Cp), 7.13-7.42 (m, 3H), $7.66(\mathrm{~d}, 1 \mathrm{H}, \mathrm{J}=7.0 \mathrm{~Hz}) . \quad{ }^{13} \mathrm{C}-\mathrm{NMR}$ $\left(\mathrm{CDCl}_{3}\right): \delta 31.30\left(\mathrm{CH}_{2}\right), 32.41(\mathrm{CH}), 42.82\left(\mathrm{CH}_{2}\right), 65.60(\mathrm{CH}, \mathrm{Cp}), 65.80(\mathrm{CH}, \mathrm{Cp}), 67.31 \mathrm{CH}$, $\mathrm{Cp}), 67.81$ (q), 68.09 (CH, Cp), $68.50(\mathrm{CH}, \mathrm{Cp}), 68.59$ (5xCH, Cp), $68.80(\mathrm{CH}, \mathrm{Cp}), 69.79(\mathrm{CH}$, $\mathrm{Cp}), 71.70(\mathrm{CH}, \mathrm{Cp}), 73.08(\mathrm{CH}, \mathrm{Cp}), 75.31(\mathrm{CH}, \mathrm{Cp}), 76.52(\mathrm{CH}, \mathrm{Cp}), 77.71(\mathrm{CH}, \mathrm{Cp}), 99.50$ $(\mathrm{q}, \mathrm{Cp}), 104.39(\mathrm{q}, \mathrm{Cp}), 122.90(\mathrm{CH}), 126.91(\mathrm{CH}), 127.57(\mathrm{CH}), 128.43(\mathrm{CH}), 131.78(\mathrm{q})$, $139.80(\mathrm{q}), 173.11(\mathrm{C}=\mathrm{N})$. FAB MS (m/z (relative intensity): $669\left(\mathrm{M}^{+}+1-\mathrm{I}, 42\right), 542\left(\mathrm{M}^{+}+1-2 \mathrm{I}\right.$, 100). Anal. Calcd for $\mathrm{C}_{31} \mathrm{H}_{27} \mathrm{Fe}_{2} \mathrm{I}_{2} \mathrm{NO}$ : C, 46.83; H, 3.42; N, 1.76. Found: C, 46.58; H, 3.17; N, 1.50 .

Preparation of 1,1'-[3-iodo-(3,4-dihydro-2,4-quinolinediyl)(2-ferrocenyl-2-hydroxy-1,2ethanediyl]ferrocene (7). A solution of $N$-iodo dihidroquinolinium yodide $6(0.1 \mathrm{~g}, 0.126$ mmol) in anhydrous $\mathrm{CHCl}_{3}$ was stirred at room temperature and under $\mathrm{N}_{2}$ atmosphere for $72 \mathrm{~h}$. The solution was filtered over a deactivated silica gel pad which was washed with $\mathrm{CH}_{2} \mathrm{Cl}_{2}(3 \times 25$ $\mathrm{ml}$ ). The solution was evaporated to dryness and the resulting residue was triturated with $\mathrm{Et}_{2} \mathrm{O} / n$ pentane to give an orange solid which was chromatographed on a silica gel column using ethyl acetate/ $n$-hexane $(1 / 1)$ as eluent to yield 7 , in $70 \%$, as an analytically solid pure sample. Mp 225 $228^{\circ} \mathrm{C}$ (d). IR (Nujol; $\mathrm{cm}^{-1}$ ) 3510, 1592, 1562, 1248, 110, 1066, 1302, 880, 831, 757, 723. ${ }^{1} \mathrm{H}-$ NMR $\left(\mathrm{CDCl}_{3}\right): \delta 1.88\left(\mathrm{dd}, 1 \mathrm{H}, \mathrm{J}_{\mathrm{gem}}=14.4 \mathrm{~Hz},{ }^{3} \mathrm{~J}=12.3 \mathrm{~Hz}\right), 2.38\left(\mathrm{dd}, 1 \mathrm{H}, \mathrm{J}_{\text {gem }}=14.4 \mathrm{~Hz}, \mathrm{~J}=\right.$ $5.4 \mathrm{~Hz}), 2.68(\mathrm{~s}, \mathrm{OH}), 3.56-3.58(\mathrm{~m}, 1 \mathrm{H}), 3.81-3.82(\mathrm{~m}, 1 \mathrm{H}, \mathrm{Cp}), 3.84-3.85$ (m, 1H, Cp), 3.943.95 (m, 1H, Cp), 4.00-4.01 (m, 1H, Cp), 4.07-4.10 (m, 1H, Cp), 4.16 (t, $\left.2 \mathrm{H}, \mathrm{Cp},{ }^{3} \mathrm{~J}=1.8 \mathrm{~Hz}\right)$, 
4.17, s, 5H, Cp), 4.45-4.50 (m, 2H, Cp), 4.59-4.61 (m, 1H, Cp), 4.92-4.93 (m, 1H, Cp), 5.02-5.03 $(\mathrm{m}, 1 \mathrm{H}, \mathrm{Cp}), 6.24\left(\mathrm{~d}, 1 \mathrm{H},{ }^{3} \mathrm{~J}=3.0 \mathrm{~Hz}\right), 7.20(\mathrm{dd}, 1 \mathrm{H}, \mathrm{J}=7.5 \mathrm{~Hz}, \mathrm{~J}=1.5 \mathrm{~Hz}), 7.29(\mathrm{dd}, 1 \mathrm{H}, \mathrm{J}=$ $7.5 \mathrm{~Hz}, \mathrm{~J}=1.2 \mathrm{~Hz}), 7.37(\mathrm{td}, 1 \mathrm{H}, \mathrm{J}=7.8 \mathrm{~Hz}, \mathrm{~J}=1.5 \mathrm{~Hz}), 7.47(\mathrm{~d}, 1 \mathrm{H}, \mathrm{J}=7.2 \mathrm{~Hz}) .{ }^{13} \mathrm{C}-\mathrm{NMR}$ $\left(\mathrm{CDCl}_{3}\right): \delta 22.05(\mathrm{CH}), 43.27(\mathrm{CH}), 43.68\left(\mathrm{CH}_{2}\right), 65.18(\mathrm{CH}, \mathrm{Cp}), 65.26(\mathrm{CH}, \mathrm{Cp}), 65.91(\mathrm{CH}$, $\mathrm{Cp}), 66.11(\mathrm{CH}, \mathrm{Cp}), 67.51$ (q), 67.97 (CH, Cp), 67.86 (CH, Cp), 67.89 (CH, Cp), 68.47 (5xCH, $\mathrm{Cp}), 68.62$ (CH, Cp), $69.31(\mathrm{CH}, \mathrm{Cp}), 69.68(\mathrm{CH}, \mathrm{Cp}), 71.36(\mathrm{CH}, \mathrm{Cp}), 73.35$ (CH, Cp), 83.21 (q, Cp), 97.87 (q, Cp), 104.6 (q, Cp), $126.47(\mathrm{CH}), 126.70(\mathrm{CH}), 126.83(\mathrm{CH}), 128.48(\mathrm{CH})$, $129.70(\mathrm{q}), 143.94(\mathrm{q}), 165.42(\mathrm{C}=\mathrm{N})$. FAB MS (m/z (relative intensity): $668\left(\mathrm{M}^{+}+1,96\right)$. Anal. Calcd for $\mathrm{C}_{31} \mathrm{H}_{26} \mathrm{Fe}_{2} \mathrm{INO}$ : C, 55.81; H, 3.93; N, 2.10. Found: C, 55.51; H, 4.21; N, 2.05 .

\section{Acknowledgements}

We gratefully acknowledge the grant from DGI-Spain CTQ 2004-02201.

\section{References and Footnotes}

1. For a detailed literature review see: (a) Ferrocenes: Homogeneus Catalysis - Organic Synthesis - Materials Sciences, Togni, A.; Hayashi, T.; Eds., VCH: Weinheim, 1995. (b) Kaifer, A. E.; Mendoza, S., In Comprehensive Supramolecular Chemistry, Vol. 1, pp 701732. Lehn, J. M.; Atwood, J. L.; Davies, J. E. D.; MacNicol, D. D.; Vögtle, F.; Eds., Pergamon: Oxford, 1996. (c) Boulas, P. L.; Gómez-Kaifer, M.; Echegoyen, L. Angew. Chem. Int. Ed. 1998, 37, 216. (d) Beer, P. D.; Gale, P. A.; Chen, G. Z. Coord. Chem. Rev. 1999, 185-186, 3. (e) Balzani, V. Ed. Electron Transfer in Chemistry, Wiley-VCH, 2001. (f) Beer, P. D.; Gale, P. A. Angew. Chem. Int. Ed. 2001, 40, 486. (g) Tucker, J. H. R.; Collinson, S. R. Chem. Soc. Rev. 2002, 31, 147. (h) Atkinson, R. C. J.; Gibson, V. C.; Long, N. J. Chem. Soc. Rev. 2004, 33, 313. (i) Peris, E. Coord. Chem. Rev. 2004, 248, 279. (j) Janowska, I.; Zarkrzewski, J.; Nakatani, K.; Palusiak, M.; Walak, M.; Scholl, H. J. Organomet. Chem. 2006, 691, 323. (k) Zhang, F.; Prosenc, M. H.; Hech, J. J. Organomet. Chem. 2006, 691, 455.

2. For a review see: Heo, R. W.; Lee, T. R. J. Organomet. Chem. 1999, 578, 31.

3. (a) Molina, P.; Tárraga, A.; López, J. L.; Martínez, J. C. J. Organomet. Chem. 1999, 584, 147. (b) Tárraga, A.; Molina, P.; López, J. L. Tetrahedron Lett. 2000, 41, 4895. (c) Tárraga, A.; Molina, P.; Curiel, D.; Velasco, M. D. Organometallics, 2001, 20, 2145. (d) Tárraga, A.; Molina, P.; Curiel, D.; Velasco, M. D. Tetrahedron Lett., 2001, 57, 6765. (e) Tárraga, A.; Molina, P.; Curiel, D. Synlett. 2002, 435. 
4. (a) Tárraga, A.; Otón, F.; Espinosa, A.; Velasco, M. D.; Molina, P.; Evans, D. J. Chem. Commun. 2004, 458. (b) López, J. L.; Tárraga, A.; Espinosa, A.; Velasco, M. D.; Molina, P.; Lloveras, V.; Vidal-Gancedo, J.; Rovira, C.; Veciana, J.; Evans, D. J.; Wurst, K. Chem. Eur. J. 2004, 10, 1815. (c) Otón, F.; Tárraga, A.; Velasco, M.D.; Espinosa, A.; Molina, P. Chem. Commun. 2004, 1658. (d) Caballero, A.; Llovera, V.; Tárraga, V.; Espinosa, A.; Velasco, M.D.; Vidal-Gancedo, J.; Rovira, C.; Wurst, K.; Molina, P.; Veciana, J. Angew. Chem. Int. Ed. 2005, 44, 1977. (e) Otón, F.; Tárraga, A.; Espinosa, A.; Velasco, M. D.; Bautista, D.; Molina, P. J. Org. Chem. 2005, 70, 6603.

5. Tárraga A.; Molina, P.; López, J. L.; Velasco, M. D.; Bautista, D.; Jones, P. G. Organometallics, 2002, 21, 2055.

6. Tárraga, A.; Molina, P.; López, J. L.; Espinosa, A.; Evans, D. J. Tetrahedron Lett. 2002, 43, 4717.

7. Bildstein, B.; Denift, P.; Wurst, K. J. Organomet. Chem. 1995, 496, 175.

8. Barlow, S.; O’Hare, D. Chem. Rev. 1997, 97, 637.

9. M. J. Pevner. Adv. Heterocycl. Chem. 1999, 75, 1. 